\title{
Risk assessment of children's exposure to potentially harmful elements (PHE) in selected urban parks of the Silesian agglomeration
}

\author{
Kicińska Alicja ${ }^{1, a}$ \\ ${ }^{1}$ AGH University of Science and Technology, Department of Environmental Protection, Faculty of Geology, Geophysics and Environmental \\ Protection, Mickiewicz av. 30, 30-052 Cracow, Poland
}

\begin{abstract}
The author determined the total contents of selected elements potentially hazardous for health (PHE): As, Be, $\mathrm{Cd}, \mathrm{Co}, \mathrm{Cu}, \mathrm{Ni}$ and $\mathrm{Sn}$ in soils, sand of sandboxes and airborne dust collected in three urban parks of the Silesian agglomeration. The upper limit of $\mathrm{Cd}$ content (a Polish regulation) was exceeded in the soils of two largest and most frequented parks, the Silesian Park and the Kościuszko Park. The mean Cd contents in soils are 9 and $7 \mathrm{mg} / \mathrm{kg}$, respectively. The metal contents of the sand from sandboxes are generally much lower than those of the soils: $\mathrm{Cu} 28$ times on average, As 13 times, and $\mathrm{Cd}$ and $\mathrm{Ni}$ around 4 times, while the Co and $\mathrm{Sn}$ contents of sand are comparable with those of soils. Airborne dusts are a significant source of metals: they contain Cd (1-20 mg/kg), Co (2-17 mg/kg) and $\mathrm{Cu}(6-143 \mathrm{mg} / \mathrm{kg})$. The quotients of the health risk indicate a potential health risk caused by $\mathrm{As}, \mathrm{Cd}$ and $\mathrm{Ni}$ for children, particularly those with a low (below $15 \mathrm{~kg}$ ) body weight. The risk level of 1-4\% PTMDI (Provisional Maximum Tolerable Daily Intake) origins from an accidental swallowing of soil.
\end{abstract}

\section{Introduction}

Several century-long traditions of bituminous coal mining and metallurgy of $\mathrm{Zn}-\mathrm{Pb}$ and $\mathrm{Fe}$ ores have left their marks not only on the landscape of Upper Silesia, but also on the environment quality and the health of local population [1, 2]. There are many papers dealing with the presence of $\mathrm{Zn}, \mathrm{Pb}$ and $\mathrm{Cd}$ in individual components of the environment (soils, air, surface waters, etc.) and with their impact on living organisms $[3,4,5,6]$. The reports on the elements generally considered to be less harmful, such as $\mathrm{Co}, \mathrm{Cu}, \mathrm{Ni}$ and $\mathrm{Sn}$, or on those with lower abundance in the nature, for instance $\mathrm{As}$ and $\mathrm{Cd}$, are rather rare. It was a reason to undertake the investigations of selected environmental components of the Upper Silesian industrial region, one of the oldest in Poland and currently the largest one. Research included the analysis of contents of some potentially hazardous elements (PHE): As, Be, Cd, Co, $\mathrm{Cu}, \mathrm{Ni}$ and $\mathrm{Sn}$, which can affect the health of population, particularly of the youngsters.

A prolonged exposure to As may lead to cancerous changes and disorders in the functioning of the nervous, circulatory and respiratory system [7]. Arsenic is commonly considered a significant source of increasing cancer-related diseases [8]. Cadmium is another element strongly toxic to human organism. The children and newborns being put at a risk of contact even with traces of $\mathrm{Cd}$ may suffer irreversible changes of their central nervous systems. Cd is also a carcinogenic element, belonging to the group I of such pathogens $[7,8]$. In turn, cobalt has got important functions in producing red blood cells, metabolism of proteins and nucleic acids. An excess of Co is a cause of damages of the thyroid, bones, kidneys, and also of the DNA structure which probably results in carcinogenic changes. An excess of copper, the next of the elements considered, although only occasionally occurring, is also hazardous to the human health. Its symptoms include nervousness, irritability and even depressions or psychosis. High build up of copper results in the Wilson disease and is linked to a mental retardation, muscular tremors and an impaired coordination of movement [7]. The nickel-containing compounds that enter the human organism via the respiratory system belong to the $1^{\text {st }}$ group of carcinogens. In excessive amounts, this element damages the structure of nucleic acids and causes tumors of the upper respiratory system. The last of the selected PHE is tin, characterized by a weak toxicity, except for its alkyl compounds that paralyze the nervous system. However, Sn is a metal of low bioavailability [5].

The aim of the investigation carried out in three urban parks of the Silesian urban agglomeration was twopronged:

1. to determine total contents of the selected PHE in the environment components which children come into contact with on playgrounds. The sample material included adjacent soils and sand of sandboxes, and also urban dusts deposited on recreational equipment and facilities used by children;

2. to establish a degree of health risk of children playing in Silesian parks.

\footnotetext{
${ }^{\text {a } C o r r e s p o n d i n g ~ a u t h o r: ~ k i c i n s k a @ g e o l o g . a g h . e d u . p 1 ~ T h i s ~ p a p e r ~ w a s ~ s u p p o r t e d ~ b y ~ A G H ~ g r a n t ~ n o . ~ 11.11 .140 .199 ~}$
} 


\section{Study area and methods}

\subsection{Study area}

The investigations were carried out in three parks of the Silesian agglomeration (Fig. 1). Two of them are the most frequented by the Upper Silesia population: the Tadeusz Kościuszko Park in Katowice (no. I in Fig. 1) with an area of 72 ha, founded in 1888, and the Śląski (Silesian) Park in Chorzów (no. III in Figure 1) with an area of 520 ha, founded in 1950. As a comparative area was chosen a small park (no. II in Fig. 1) of a housing development Bażantowo in the Kostuchna district of Katowice. The area of this park is barely 0.08 ha.

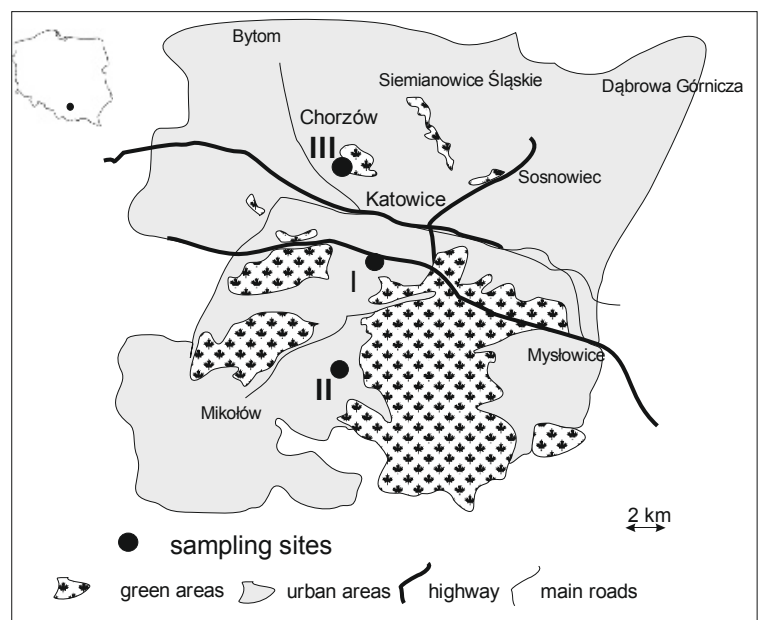

Figure 1. Samplings sites: I - Kościuszko Park in Katowice, II - Park in Kostuchna district of Katowice, III - Silesian Park in Chorzów.

\subsection{Sampling and measurement procedures}

In each of both large parks three sampling sites within the playgrounds including sandboxes were selected. In each of them the author collected 15 samples of the topsoil (around $1 \mathrm{~kg}$ each), 15 samples of sand (around $1 \mathrm{~kg}$ each) and 5 samples of urban dusts rinsed with distilled water from the toys and playing facilities ( $1 \mathrm{dm}^{3}$ each). In the small comparative park the list of sample types was the same, but only five samples of each type were taken because of its considerably smaller area ( 3 and 4 orders of magnitude).

From the topsoil samples (a depth of $0-30 \mathrm{~cm}$ ) the grain fraction $>2 \mathrm{~mm}$ and plant fragments were removed, next the material was dried, homogenized and quartered. All kinds of analytical samples were dissolved in a mixture of concentrated acids $\left(\mathrm{HNO}_{3}\right.$, $\mathrm{HClO}_{4}$ and $\mathrm{HCl}$ ) in a microwave oven, at a solid to liquid ratio of 1:20. Then, the concentrations of $\mathrm{As}, \mathrm{Be}, \mathrm{Cd}, \mathrm{Co}$, $\mathrm{Cu}, \mathrm{Ni}$ and $\mathrm{Sn}$ in the solutions were determined with an ICP-MS analyser at a detection limits of $0.2 \cdot 10^{-5}$ $\mathrm{mg} / \mathrm{dm}^{3}$. The active (in $\mathrm{H}_{2} \mathrm{O}$ ) reaction of soils was determined at a solid to liquid ratio of 1:5.

The health risk was calculated according to the following formula [9]:

$$
D=C \cdot \frac{L C}{B W} \cdot \frac{F E}{T}
$$

where:

$D$ - dose of metal absorbed ( $\mu \mathrm{g} / \mathrm{kg}$ body weight $/$ day),

$C$ - concentration of a heavy metal in soil $(\mathrm{mg} / \mathrm{kg})$,

$L C$ - length of contact with a soil per unit of time (accepted as $200 \mathrm{mg}$ soil/day),

$F E$ - frequency of exposure (accepted as 2 hours/day),

$B W$ - body weight (accepted as $15 \mathrm{~kg}$ for a three-year-old child and $19 \mathrm{~kg}$ for a six-year-old child),

$T$ - time of exposure (accepted as 1050 days for threeyear-old child or 2100 days for six-year-old child).

\section{Results}

\subsection{PHE in soils}

The $\mathrm{pH}$ of soils varied from 5.7 to 6.8 , classifying them [10] as slightly acid, which results from the prevalence of luvisols and brown soils in the area. The lowest $\mathrm{pH}$ values were determined in the park no. II (mean 5.73), in the other two parks the mean $\mathrm{pH}$ values are almost equal (6.1-6.2).

The contents of As in soil ranges from 2.3 to $6.1 \mathrm{mg} / \mathrm{kg}$ (Tab. 1), with the highest mean $(4.1 \mathrm{mg} / \mathrm{kg})$ calculated for the park no. I and a slightly lower mean $(3.8 \mathrm{mg} / \mathrm{kg})$ for the park no. III. Distinctly lower is the calculated As mean contents of the soils in park no. II $-2.3 \mathrm{mg} / \mathrm{kg}$. Similar trends have been found in the case of $\mathrm{Co}, \mathrm{Cu}, \mathrm{Ni}$ and Sn (Tab. 1). The highest mean soil contents of these elements occur in the park no. I $(12,25,23$ and $5 \mathrm{mg} / \mathrm{kg}$, respectively), slightly lower in the park no. III $(11,15,12$ and $4 \mathrm{mg} / \mathrm{kg}$, respectively), and distinctly lower in the park no. II (7, 5, 9 and $1 \mathrm{mg} / \mathrm{kg}$, respectively).

Table 1. PHE content in soils from Silesia playground.

\begin{tabular}{|c|c|c|c|c|c|c|c|}
\hline \multirow[t]{2}{*}{ Park } & \multirow[t]{2}{*}{$\mathrm{n}$} & As & Cd & Co & $\mathbf{C u}$ & $\mathbf{N i}$ & Sn \\
\hline & & \multicolumn{6}{|c|}{$[\mathrm{mg} / \mathrm{kg}]$} \\
\hline I & 15 & 4.1 & 7 & 12 & 25 & 23 & 5 \\
\hline II & 5 & 2.3 & 3 & 7 & 5 & 9 & 1 \\
\hline III & 15 & 3.8 & 9 & 11 & 15 & 12 & 4 \\
\hline $\min .-\max$ & \multirow{3}{*}{35} & $2.3-6.1$ & $3-12$ & $7-19$ & $5-45$ & $7-40$ & $1-7$ \\
\hline av. & & 3.7 & 7.4 & 11 & 31 & 16.5 & 4 \\
\hline$S D$ & & 0.07 & 0.16 & 0.12 & 0.14 & 0.3 & 0.02 \\
\hline \multirow{2}{*}{$\begin{array}{l}\text { accept. } \\
\text { values* }\end{array}$} & A & 20 & 1 & 20 & 30 & 35 & 20 \\
\hline & B & 20 & 4 & 20 & 150 & 100 & 20 \\
\hline
\end{tabular}

*Due to [11]: $\mathrm{A}$ - protected areas, $\mathrm{B}$ - other areas, $\mathrm{n}$ - number of samples, min. - minimum, max. - maximum, av. - average arithmetic, $S D$ - standard deviation.

The contents of all the PHE within the park no. I are the highest in the soils of the sampling site no. 2 (Fig. 2). In the park no. III the differences among the PHE contents of soils are less significant than in the park no. I, being the highest in the sampling site no. 2 (Fig. 3). In both parks these two sites are located relatively far from major town transit systems and the park playgrounds have been set in open areas (without shrubs and higher trees). Their significant contaminations must be, thus, related to the fall 
of airborne particles containing heavy metals among various pollutants.

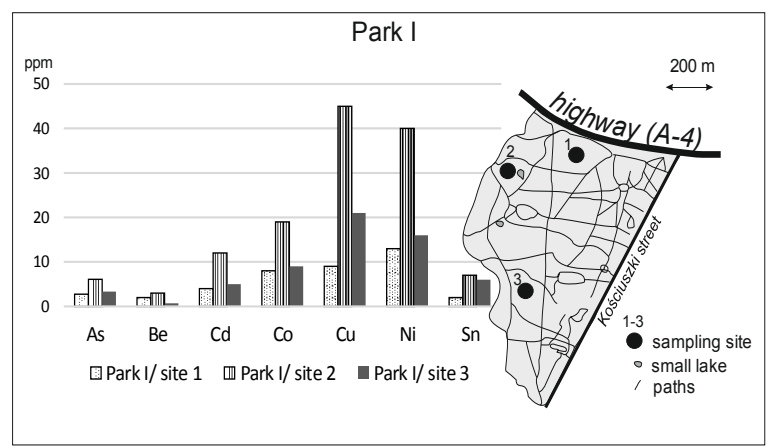

Figure 2. The concentration of PHE in Kościuszko Park in Katowice.

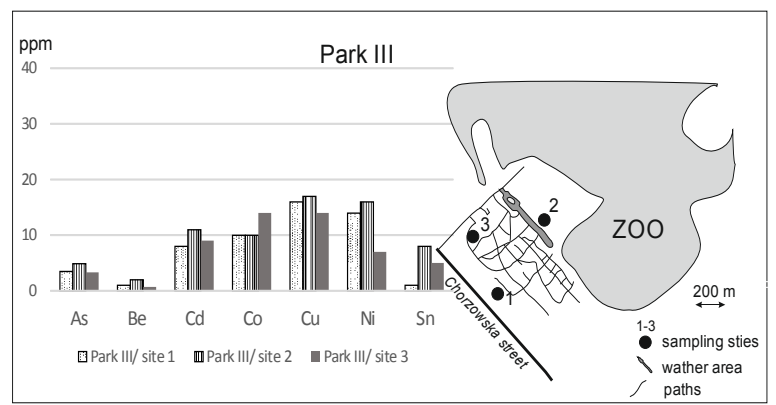

Figure 3. The concentration of PHE in Silesian Park in Chorzów.

The soil metal values of the three parks do not exceed upper permitted values of $\mathrm{As}$, Co and $\mathrm{Sn}(20 \mathrm{mg} / \mathrm{kg}$ for each of them) of the Polish soil quality standards established by the Minister of the Environment [11] for the soils of the protected areas (i.e., the areas A). In the case of $\mathrm{Ni}$ and $\mathrm{Cu}$, their limits of 35 and $30 \mathrm{mg} / \mathrm{kg}$ respectively, have been exceeded in respect to the type A soils for all the samples collected in the sites no. 2 of the parks no I and no. III. However, the upper limits of the metal contents of the soils occurring in the areas other than the protected and industrial ones (i.e., the areas B) have not been exceeded for $\mathrm{Ni}$ and $\mathrm{Cu}$.

The cadmium soil contents of the playgrounds are most burdensome. They exceed generally not only $1 \mathrm{mg} / \mathrm{kg}$, which is the upper border for soils of the protected areas (type A), but also $4 \mathrm{mg} / \mathrm{kg}$, the upper limit of the type B areas (i.e., the areas other than protected and industrial ones). The exception make the soils of the park no. II, whose mean $\mathrm{Cd}$ content is $3 \mathrm{mg} / \mathrm{kg}$ and classifies them in this respect between the protected and industrial soils.

\subsection{PHE in sand}

Common habit of young children which is putting dirty hands into the mouth, is a serious hazard of entering significant amounts of toxins into their organisms via the digestive tract. Therefore, the sand of the sandboxes, if metal-contaminated represents the same threat as contaminated, soils if accidentally swallowed by children. The metal contents of sand samples (Tab. 2) are generally lower than the contents of the same PHE determined in the soils. Their means are 13 times the lower in the case of As, 4 times in the case of Cd, and 29 times in the case of $\mathrm{Cu}$. The quantities of the PHE of sand range as follows: As $0.12-0.65, \mathrm{Cd} \mathrm{1-3,} \mathrm{Co} \mathrm{5-14,} \mathrm{Cu} 0.4-4 \mathrm{Ni}$ 4-9 and $\mathrm{Sn} 1-7 \mathrm{mg} / \mathrm{kg}$.

Table 2. PHE content in sand from Silesia playground.

\begin{tabular}{|c|c|c|c|c|c|c|c|c|}
\hline & & As & Cd & Co & Cu & Ni & Sn \\
\cline { 3 - 8 } Park & $\mathrm{n}$ & \multicolumn{7}{|c|}{$[\mathrm{mg} / \mathrm{kg}]$} \\
\hline I & 15 & 0.38 & 2 & 10 & 1.6 & 7 & 4.6 \\
\hline II & 5 & 0.18 & 2 & 12 & 0.4 & 6 & 5 \\
\hline III & 15 & 0.21 & 2 & 8 & 0.7 & 4 & 1.6 \\
\hline min. -max. & & $0.12-0.65$ & $1-3$ & $5-14$ & $0.4-4$ & $4-9$ & $1-7$ \\
av. & 35 & 0.28 & 2 & 9.8 & 1.1 & 6.8 & 3.4 \\
SD & & 0.03 & 0.04 & 0.1 & 0.02 & 0.1 & 0.01 \\
\hline
\end{tabular}

$\mathrm{n}$ - number of samples, min. - minimum, max. - maximum, av. - average arithmetic, $S D$ - standard deviation.

The sand samples of the park no. II are an exception as they contain higher mean quantities of cobalt and tin than those established for soils. Their mean metal quantities of sand and soil are 12 and $7 \mathrm{mg} / \mathrm{kg}$ of $\mathrm{Co}$, and 5 and $1 \mathrm{mg} / \mathrm{kg}$ of $\mathrm{Sn}$.

\subsection{PHE in dusts}

The most contaminated soils and sand in the parks no's I and III have been found in their sampling sites numbered 2. Both of them are exposed to a relatively free fall of airborne dusts.

The mean of arsenic and tin quantities in the playing ground dusts are considerably lower than those of soils: calculated for all the samples they are 7 times lower in the case of As and 13 times lower in the case of Sn. The quantities of $\mathrm{Cu}$ and $\mathrm{Ni}$ are comparable and also those of $\mathrm{Cd}$ and Co (Tab. 3).

Table 3. PHE content in dusts from Silesia playground.

\begin{tabular}{|c|c|c|c|c|c|c|c|c|}
\hline & & As & Cd & Co & Cu & Ni & Sn \\
\cline { 3 - 8 } Park & $\mathrm{n}$ & \multicolumn{6}{|c|}{$[\mathrm{mg} / \mathrm{kg}]$} \\
\hline I & 5 & 0.44 & 5 & 8 & 19 & 7 & 0.37 \\
\hline II & 5 & 0.74 & 8 & 10 & 25 & 10 & 0.28 \\
\hline III & 5 & 0.47 & 7 & 7 & 60 & 34 & 0.27 \\
\hline min.-max. & & $0.36-0.74$ & $1-20$ & $2-17$ & $6-143$ & $9-34$ & $0.19-0.41$ \\
av. & 15 & 0.5 & 6.5 & 8.1 & 38 & 15 & 0.31 \\
SD & & 0.07 & 0.15 & 0.12 & 0.81 & 0.33 & 0.03 \\
\hline
\end{tabular}

$\mathrm{n}$ - number of samples, min. - minimum, max. - maximum, av. - average arithmetic, $S D$ - standard deviation.

A comparison of the metal contents of dusts to those of sand shows higher quantities of $\mathrm{As}$ and $\mathrm{Ni}$ (around 2 times), $\mathrm{Cd}$ (3 times) and $\mathrm{Cu}$ (even 34 times) and lower of Co (slightly) and Sn (even 10 times).

The results indicate a significant contribution of dusts to the contamination of the park soils with $\mathrm{Cd}, \mathrm{Co}, \mathrm{Cu}$ and $\mathrm{Ni}$.

\subsection{Risk assessment of the children's health}

A health risk of children resulting from the presence of metals in the environment was evaluated by calculating 
a daily intake of the metals (D) using the formula (1). The following assumptions were made: the daily quantity of accidentally swallowed soil is $200 \mathrm{mg}$, an average body mass of a three-year-old child is $15 \mathrm{~kg}$ and that of a sixyear-old child $19 \mathrm{~kg}$, a daily exposure to a toxic element is 2 hours. The daily doses D (Tab. 4) do not exceed in all the parks the permitted values of the Provisional Maximum Tolerable Daily Intake (PTMDI) values recommended by the WHO [12-16]. Cadmium present in soils is a troublesome element, particularly for the youngsters of age below 3 years and for the threeyear-old children of the body mass below $15 \mathrm{~kg}$. The doses D calculated for the parks no's III and I are 4\% PTMDI, whereas slightly above $1 \%$ PTMDI for $\mathrm{As}$ and $\mathrm{Ni}$ in the case of younger children.

Table 4. Potential intake of PHE by children in the case of incidental swallowing of soil in Silesian playground.

\begin{tabular}{|c|c|c|c|c|c|c|}
\hline \multirow{3}{*}{ Park } & \multicolumn{2}{|c|}{ As } & \multicolumn{2}{|c|}{ Cd } & \multicolumn{2}{|c|}{ Co } \\
\hline & $15 \mathrm{~kg}$ & $19 \mathrm{~kg}$ & $15 \mathrm{~kg}$ & $19 \mathrm{~kg}$ & $15 \mathrm{~kg}$ & $19 \mathrm{~kg}$ \\
\hline & \multicolumn{6}{|c|}{$\mu \mathrm{g} / \mathrm{kg}$ bw per day } \\
\hline I & 0.10 & 0.04 & 0.19 & 0.07 & 0.30 & 0.12 \\
\hline II & 0.06 & 0.02 & 0.08 & 0.03 & 0.18 & 0.07 \\
\hline III & 0.10 & 0.04 & 0.23 & 0.09 & 0.28 & 0.11 \\
\hline \multirow[b]{2}{*}{ PTMDI* } & \multicolumn{2}{|c|}{2} & \multicolumn{2}{|c|}{0.36} & \multicolumn{2}{|c|}{-} \\
\hline & 30 & 38 & 5.4 & 6.84 & - & - \\
\hline \multirow{3}{*}{ Park } & \multicolumn{2}{|c|}{$\mathrm{Cu}$} & \multicolumn{2}{|c|}{$\mathbf{N i}$} & \multicolumn{2}{|c|}{ Sn } \\
\hline & $15 \mathrm{~kg}$ & $19 \mathrm{~kg}$ & $15 \mathrm{~kg}$ & $19 \mathrm{~kg}$ & $15 \mathrm{~kg}$ & $19 \mathrm{~kg}$ \\
\hline & \multicolumn{6}{|c|}{$\mu \mathrm{g} / \mathrm{kg}$ bw per day } \\
\hline $\mathrm{I}$ & 0.63 & 0.25 & 0.58 & 0.23 & 0.13 & 0.05 \\
\hline II & 0.13 & 0.05 & 0.23 & 0.09 & 0.03 & 0.01 \\
\hline III & 0.38 & 0.15 & 0.30 & 0.12 & 0.10 & 0.04 \\
\hline \multirow[b]{2}{*}{ PTMDI* } & \multicolumn{2}{|c|}{500} & \multicolumn{2}{|c|}{5} & \multicolumn{2}{|c|}{2000} \\
\hline & 7500 & 9500 & 75 & 95 & 30000 & 38000 \\
\hline
\end{tabular}

* Provisional Max. Tolerable Daily Intake due to [12-16]" -“" lack data

It considered that only parts of the total quantities of the elements are bioavailable and can enter via the digestive tract the chain of metabolic transformations [5]. On the other hand it also has to be considered that the metal absorption of children is higher than that of adults, and the children are additionally sensitive to metal absorption via the respiratory tract and the skin [17]. Besides, the investigations of the regions affected by the mining and metallurgical industries have revealed that the cation exchangeable and easily leachable carbonate-bound metal forms may contribute in the case of cadmium even to $60-70 \%$ of its totals [18].

\section{Conclusion}

The determination of the total quantities of the selected PHE in soils of the playing grounds in three urban parks of the Silesian agglomeration make the basis of the pollution assessment of this environmental segment. The worse is cadmium pollution of two largest and most frequented parks: the Silesian one in Chorzów and the Kościuszko one in Katowice. In both of them the Cd contents of soils exceed the upper limit of the B- type soils set in the Regulation of the Minister of the Environment [11]. Lower than permitted quantities of all the PHE considered characterize the soils of the park no. II, located within a new housing development in Katowice, as well as the $\mathrm{As}, \mathrm{Cd}$ and $\mathrm{Cu}$ contents of playground sand. However, the park toys and recreation facilities of this park are covered with airborne dusts with the highest As, $\mathrm{Cd}$ and Co quantities. The highest quantities of $\mathrm{As}, \mathrm{Co}, \mathrm{Cu}, \mathrm{Ni}$ and $\mathrm{Sn}$ occur in the soils of the park no. I except of the $\mathrm{Cd}$ contents being the highest in the park no. III.

In sand of the park sandboxes the metal contents are significantly lower than those of soils, which is due to the inert chemical nature of quartz grains, by far the major component of every sand. The metal contents of the sand originate from airborne dusts, which are carriers of many elements, particularly of $\mathrm{Cd}$, $\mathrm{Co}$ and $\mathrm{Cu}$.

The quotients of the health risk indicate to a potential risk of As, Cd and $\mathrm{Ni}$ for children, particularly for those with a low body weight, less than $15 \mathrm{~kg}$. The risk level is $1-4 \%$ PTMDI and results from an accidental (via dirty hands) swallowing of soil. This finding requires attention because $\mathrm{As}, \mathrm{Cd}$ and $\mathrm{Ni}$ are toxic and included in the group I of carcinogens.

\section{References}

1. E. Wcisło, J. Bronder, J. Długosz, M. Korcz, Ocena środowiskowych zagrożeń mieszkańców dużych miast Polski, Wyd. Ekon. i Środ., Białystok, 132 (2008)

2. E. Wcisło, Ocena ryzyka zdrowotnego(..), Wyd. Ekon. i Środ., Białystok, 29-63 (2009)

3. I. Norska-Borówka, J. Bursa, J. Rzempołuch, R. Wawryk, Arch. Ochr. Środ., 3-4 (1990)

4. G. Dziubanek, R. Baranowska, K. Oleksiuk, J. Ecol Health. 16, 4 (2012).

5. K. Ljung, A. Oomen, M. Duits, O. Selinus, M. Berglund, J. Environ. Sc. Health Part A, Tox. Hazard. Subst. Environ. Eng. 42, 9, 1241 (2007).

6. J. Nieć, R. Baranowska, G. Dziubanek, D. Rogala D, J. Ecol. Health. 17, 2 (2013).

7. A. Kabata-Pendias, B. Szteke, Pierwiastki śladowe w geo- i biosferze, Puławy (2012)

8. A. Kabata-Pendias, H. Pendias, Biogeochemia pierwiastków śladowych, PWN, Warszawa (1999)

9. J. B. Diatta, W. Grzebisz. Polish J. Envi. Stu. 20, 6 (2011)

10. BN-75/9180-03 Oznaczanie wartości pH.

11. Roz. Min. Środ. Dz.U. 2002 nr 165, poz. 1359.

12. WHO, Techn. Rep. Ser. 776, Geneva (1989)

13. WHO, Food Add. Ser. No. 17, Geneva (1982)

14. WHO, Guid. for drink. water. qual.2, Geneva (1996)

15. EFSA J. $10: 2551-2558$ (2012)

16. IECFA, FAO/WHO, Rome (2005)

17. US EPA: Guidelines for Human Health Risk assessment of Chemical Mixtures. Federal Register (51 FR 34014-34025), Washington (1986).

18. A. Kicińska, Envir. Prot. \& Natur. Res. 49 (2011) 